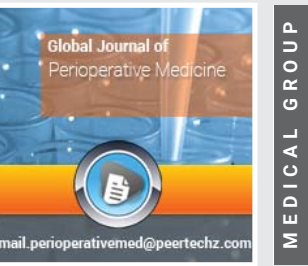

\section{The effectiveness of the} concept ERAS (Enhanced Recovery After Surgery) in patients of surgical intensive

\section{care unit}

\author{
Jana Richtarova ${ }^{1,2 *}$, Eva Mrazkova ${ }^{1,3,4}$ and Igor Satinsky ${ }^{2,5}$ \\ ${ }^{1}$ The Institute of Epidemiology and Public Health Protection, Faculty of Medicine, Ostrava University, \\ Ostrava, Czech Republic \\ ${ }^{2}$ Department of Multidisciplinary Intensive Care Unit, Hospital with Polyclinic Havirov, Havirov, Czech \\ Republic
}

${ }^{3}$ Department of Otorhinolaryngology and Head and Neck Surgery, Hospital with Polyclinic Havirov, Havirov, Czech Republic

${ }^{4}$ Centre for Hearing and Balance Disorders, Ostrava, Czech Republic

${ }^{5}$ The Institute of Nursing, Faculty of Public Policies, Silesian University, Opava, Czech Republic
Received: 08 June, 2020

Accepted: 08 July, 2020

Published: 09 July, 2020

*Corresponding author: Jana Richtarová, Institute of Epidemiology and Public Health Protection, Faculty of Medicine, Ostrava University, Ostrava, Czech Republic, E-mail: jana.richtarova@nsphav.cz

Keywords: Enhanced recovery after surgery; Fasttrack surgery; Perioperative care; Postoperative complications; Length of hospitalization; Surgery

https://www.peertechz.com

Check for updates

\title{
Summary
}

Introduction: The objective of the survey study is to the accessible world literature sources and comparative studies dealing with the effectivity of the ERAS concept in the patients after the surgical interventions in the surgical emergency units and to present adoption of concept in the Czech Republic.

Method: For searching of the needed information and data they were used the literature sources and comparative studies from the open access and licensed database sources (Scopus, SpringerLink, Medline Complete, ScienceDirect, Web of Science, ProQuest, EBSCOhost, Wiley Online Library). The conclusions of the concrete comparative studies dealing with the conceptual effectivity of the perioperative care ERAS were analysed. On the analytical base of the gained information drawing from the accessible literature and from 8 quantitative studies published in the years 2009-2013.

Results: It is clear that following of the ERAS protocol principle in the surgical workplaces in the Czech Republic is adopted only in the limitation of the routine application of the nasogastric probe, application of epidural analgesia and parenteral preoperative nutritional support if enteral not possible.

Conclusion: The positive effect of the new way of the perioperative care, ERAS is proved as for the qualitative improvement of the treatment and nursing process, as for decreasing of the postoperative complications and shortening of the hospitalization period including decreasing of the economic expenditures connected to the treatment and hospitalization of the surgical patients. In comparison with established ERAS protocol, in the Czech Republic the principles are put into effect less significantly. The mentioned experiences and results can be the useful source for the next surgical workplaces.

\section{Introduction}

ERAS - Enhanced Recovery After Surgery (also called Fast-track surgery) is the concept of the perioperative care, leading to quicker and safer perioperative course after surgical interventions (decreasing of the perioperative stress, minimizing of the postoperative complications, shortening of the hospitalization period, the economic benefit) [1-8]. 
The concept dating back to 90's started with the colorectal surgery. Prof. Henrik Kehlet (The Center of Surgical Pathophysiology in Copenhagen) along with prof. Douglas W. Wilmore from The Medical Faculty of The Boston University are considered to be pioneers of this new concept $[1,2]$.

ERAS is about the complex and mutually connected multiprofessional access (a psychologist, an anaesthetist, a surgeon, an intensivist, an internist, a rehabilitation specialist, and the non-medical health staff) which participate in the patient's perioperative care. The mentioned access is adopted mostly in the planned surgical interventions $[1,3-6,9,10]$.

Following of the ERAS protocol is advised by The European Society for the Enhanced Postoperative Rehabilitation (ERAS society) and The European Society for the Parenteral and Enteral Nutrition (ESPEN). The individual principles of the ERAS protocol are also verified by the scientific proofs of EBM (Evidence-Based Medicine), based on the results of the randomized trials and the subsequent meta-analyses [1,47,9,11-14].

Despite of the clear scientific proof, the adoption of the ERAS protocol faces many problems in the workplaces all over the world. The aim of the message is, with the analysis of literature sources which deal with effectivity of the ERAS method, to describe situation of adoption ERAS protocol in the Czech Republic and to compare the traditional concept of the perioperative care with the specific aspects of the ERAS protocol at the intervention fields, which are fundamental ones.

\section{Selective criteria}

For the literature analysis, they were chosen the articles or chapters in the expert publications concerning the given problems. It was mostly about the comparative trials observing the introduction of the individual items of the ERAS concept in practice. The authors of the trials analysed the effectivity of the applied items of the ERAS concept in the observed workplaces. The analysis was aimed at the observation of the patients which underwent the demanding surgical interventions and their postoperative period spent in the intensive care clinical bed. The results drawing on the gained literature sources concerned in the concrete mainly of the early recovery of the peroral or parenteral intake, non-aggressive fluid replacement, early removing of the nasogastric probe, non-functional drains, and catheters. The study of the expert literature was also aimed at the problems of the early mobilization. By means of the excluding criteria they were the expert articles and studies concerning the preoperative period and operation stage which take place outside of the intensive care unit and thus the individual procedures, which are characteristic for the mentioned periods were not the subject of the deeper analysis in this message.

\section{Sources}

The literature sources and studies dealing with the ERAS method effectivity were looked up in the licensed and open access databases Scopus, SpringerLink, Medline Complete, ScienceDirect, Web of Science, ProQuest, EBSCOhost, Wiley Online Library (the period from 2005 till 2015).

\section{Search}

For searching it was used the logical search operator and then it was entered the various combination of the following key words: ERAS, the perioperative care, postoperative complications, hospitalization period, surgery, fasttrack surgery, enhanced recovery after surgery, surgery, perioperative care, postoperative complications, length of hospitalization, surgery.

\section{Selection and analysis of studies}

In this way it was found all in all 77 of the expert articles from that 8 duplicate articles were immediately removed. After reading of the article annotation and verification which articles will suit to our selected criteria, unused articles were removed along with unsuitable ones. The gradual removing of the expert articles according to the recommendation of PRISMA [15] shows the scheme No: 1 . The expert information and data were obtained from the review articles, the original papers, the systematic reviews, the instructions, the expert analyses and results of the national survey. The literature analysis were also performed except of the above mentioned, with the eight quantitative studies (the two comparative studies, one randomized prospective study, one controlled randomized study, two meta-analytical randomized controlled studies, one prospective randomized controlled study, one randomized study), they were no qualitative studies in the article selection. The found proofs were evaluated on the hierarchic base level of the proofs, according to the authors which classify the proofs into the seven categories. The proofs of the level Ia and III were included in our overview article [16].

\section{Results}

The results are based on the analysis of the eight quantitative studies (Table 1), the next related expert information and data were gained from the overview articles, original papers, systematic reviews, instructions, expert analyses and results of the national survey.

Vlug, et al. evaluate the possible influence the independent determinants in their study (the female sex, laparoscopic resection, postoperative diet, forced postoperative mobilization) on the quicker recovery. [4]. Šerclová also shows in her prospective study a quicker recovery by means of introduction of the individual principles of the fast-track concept especially in the field of the controlled postoperative pain and the earlier recovery of the patient's intestinal passage [17]. The conclusions of the performed randomized controlled study identify with the above-mentioned claims. The study was published by Wang, et al. it shows the realization of the present ERAS concept which leads to the earlier recovery of the intestinal function and acceleration of the postoperative recovery [18].

The clinical randomized study focuses on length of the hospitalization period comparing the effect of traditional care against the modern procedures in the perioperative care [19]. Thanks to the ERAS protocol it was reduced the hospital stay including the expenditures connected to the stay. Varadhan 


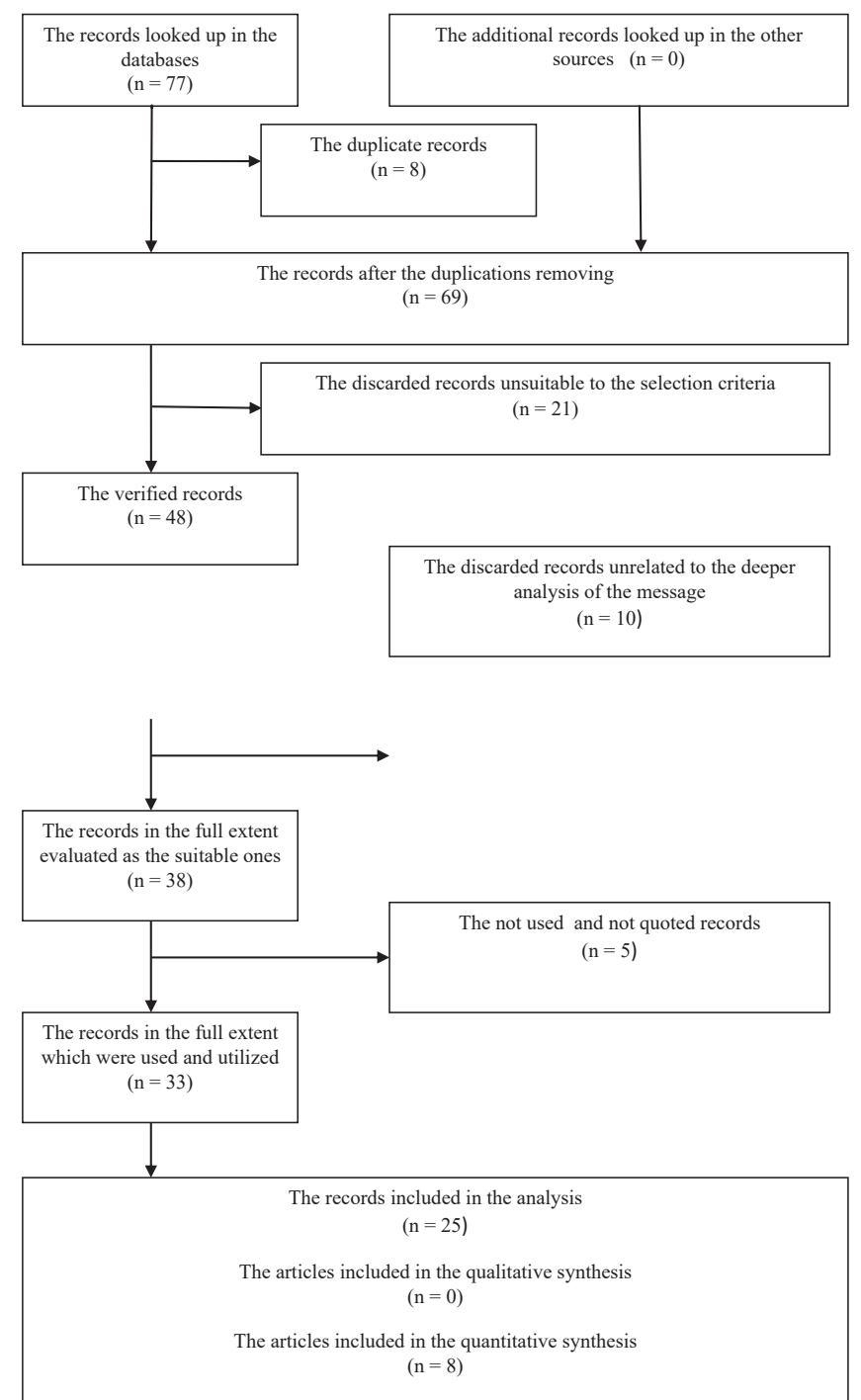

The scheme No.1: The flowchart - the recommendation according to PRISMA.

positively evaluates not only the reduction of hospital stay but the less occurrence of the possible complication after the big-opened intestinal operations [20]. Gouvas, et al. confirm by means of the meta-analyses of the randomized studies that following of the fast-track concept leads to shortening of the hospital stay and the patient's safety is not jeopardized [8]. Ren, et al. in their prospective randomized controlled study pay attention to the selected aspects of the ERAS protocol and their implementation in practice, as well. It shows the better nutritive state, the less stress reactions, and the quicker recovery in the observed patients [21]. Hübner, et al. by means of the randomized study, proved the negative impact of the fluid restriction and epidural analgesia according to the fast-track concept on the haemodynamic stability and renal dysfunction [22].

\section{Intake per Os in postoperative period}

The traditional access of the early recovery of peroral intake lies in following steps - nothing per os in the operation day, the limited amount of allowed fluids in the 1st postoperative day, soft food diet only during the recovery of intestinal peristalsis $[1,23]$.
For the ERAS concept it is the standard procedure now vice-versa the early recovery of peroral intake in the day of performed intervention. If we compare the traditional access to the fast-track principles than the fluids are already served out to the patients after 2-3 hours from the performed operation, the yoghurts, bouillons, sponge cakes are served out in the evening. During the first postoperative day they are served out the snack, sponge cakes, bouillons, the liquid nutritional diet, and soft food diet according to the patient's tolerance, as well. During the second operation day it is served out soft food diet according to the patient's tolerance again or it is fluently changed to the patient's standard diet regimen. It is kept a record of the portion of eaten serving, the effort towards the nutritional therapeutant's presence during the morning doctor's round [24].

The concept ERAS was performed in the patients suffering from the colorectal cancer from the beginning, now it is also used i.e. in the oesophageal, pancreatic, and gastric operations. It even exceeds the scope of surgery in itself and it directs to the urological, gynaecological, and obstetric field [25].

\section{Enteral probe alimentation}

The enteral alimentation is the important treatment part of the patients and serving meal is one of the base competences of a nurse. The supposed insufficient food intake per os in the postoperative period means the indication for the enteral probe alimentation in the emergency ward in the fast-track concept. In case the digestive system is able to admit and process the food, the patient can be nourished by means of the nasoenteral probes (the nasogastric or nasojejunal probe) or jejunostomia.

In the fast-track concept it is the enteral probe alimentation especially used in the vast operations of the upper gastrointestinal tract when the enteral probe access into the gastro-intestinal tract is performed during the operation.

The enteral alimentation can be continually applied by means of the enteral pumps providing the gradual velocity increase $(20 . . .50 \ldots 120 \mathrm{ml} / \mathrm{hrs}$.) according to the actual energetic and nutritional needs and according to the patient's nutritional tolerance. It can be also applied in the form of boluses (the single application of the bigger amount). If the patient does not tolerate the given enteral alimentation, it comes about the finishing of the application for the period of 6 or 12 hours and after the expiry of the mentioned period the alimentation is started again and it is chosen the half setting of the original velocity. It is suitable the existence of written consensual recommendation for the given workplace.

The enteral alimentation by means of a probe is not the contraindication for per os intake, the patients are allowed to take the fluids, it is about the so called „drinking round the probe".

\section{Infusion therapy in perioperation period}

It is necessary the adequate fluid intake in the patients in the perioperative period. It is important to fill the fluid volume loss in the vascular bloodstream to achieve of the normal 
Table 1: The overview of studies evaluating the effectivity of the ERAS method.

\begin{tabular}{|c|c|c|c|c|c|}
\hline The author & $\begin{array}{c}\text { The evaluated field } \\
\text { of needs }\end{array}$ & The method/type of the study & The set & The needs/results & $\begin{array}{c}\text { The level of } \\
\text { proofs }\end{array}$ \\
\hline $\begin{array}{l}\text { Vlug MS, et al. } \\
\qquad[4]\end{array}$ & Biological & $\begin{array}{l}\text { The quantitative comparation } \\
\text { study }\end{array}$ & $\begin{array}{l}\quad 400 \text { patients } \\
\text { with Fast-track (FT) }\end{array}$ & $\begin{array}{l}\text { Recovery - the list of the independent determinants for } \\
\text { the quicker recovery: female sex, laparoscopic resection, } \\
\text { postoperative diet, forced postoperative mobilization. }\end{array}$ & III \\
\hline $\begin{array}{c}\text { Šerclová Z, et al. } \\
{[17]}\end{array}$ & Biological & $\begin{array}{l}\text { The quantitative randomized } \\
\text { prospective study }\end{array}$ & $\begin{array}{c}103 \text { patients } \mathrm{FT}=51 \\
\text { non- } \mathrm{FT}=52\end{array}$ & $\begin{array}{l}\text { Recovery - FT leads to the quicker recovery of intestinal } \\
\text { function and it significantly participates in control of the } \\
\text { postoperative pain. }\end{array}$ & III \\
\hline $\begin{array}{l}\text { Wang Q, et al. } \\
\qquad[18]\end{array}$ & Biological & $\begin{array}{l}\text { The quantitative randomized } \\
\text { controlled study }\end{array}$ & $\begin{array}{c}78 \text { patients } \mathrm{FT}=40 \\
\text { non- } \mathrm{FT}=38\end{array}$ & $\begin{array}{l}\text { Recovery - FT shortened the recovery time of intestinal } \\
\text { function and accelerated the postoperative recovery. }\end{array}$ & III \\
\hline $\begin{array}{l}\text { Lemanu DP, } \\
\text { et al. } \\
\text { [19] }\end{array}$ & $\begin{array}{l}\text { Biological and } \\
\text { material }\end{array}$ & $\begin{array}{l}\text { The quantitative randomized } \\
\text { clinical comparative study }\end{array}$ & $\begin{array}{c}116 \text { patients } \mathrm{FT}=78 \\
\text { non- } \mathrm{FT}=38\end{array}$ & $\begin{array}{l}\text { The hospital stay - The protocol ERAS reduced the hospital } \\
\text { stay including the cost effectivity. }\end{array}$ & III \\
\hline $\begin{array}{l}\text { Varadhan KK, } \\
\text { et al. } \\
\text { [20] }\end{array}$ & Biological & $\begin{array}{l}\text { The quantitative meta-analysis } \\
\text { of the randomized controlled } \\
\text { studies }\end{array}$ & 452 patients & $\begin{array}{c}\text { The hospital stay - ERAS decreases length of the hospital } \\
\text { stay and complications after the big opened intestinal } \\
\text { operations. }\end{array}$ & la \\
\hline $\begin{array}{l}\text { Gouvas N, et al. } \\
{[8]}\end{array}$ & Biological & $\begin{array}{l}\text { The quantitative meta-analysis } \\
\text { of the randomized controlled } \\
\text { studies }\end{array}$ & 1021 patients & $\begin{array}{l}\text { The hospital stay - FT shortens the primary and total hospital } \\
\text { stay without the jeopardy of patient's safety. }\end{array}$ & la \\
\hline $\begin{array}{l}\text { Ren L, et al. } \\
\quad[21]\end{array}$ & $\begin{array}{l}\text { Biological and } \\
\text { mental }\end{array}$ & $\begin{array}{l}\text { The quantitative prospective } \\
\text { randomized controlled study }\end{array}$ & $\begin{aligned} & 597 \text { patients } \\
\mathrm{FT}= & 299, \text { non-FT }=298\end{aligned}$ & $\begin{array}{c}\text { The nutrition - ERAS shows the better nutritional state, } \\
\text { the lesser stress reactions and it accelerates the recovery } \\
\text { process. }\end{array}$ & III \\
\hline $\begin{array}{l}\text { Hübner } \mathrm{M} \text {, et al. } \\
{[22]}\end{array}$ & Biological & $\begin{array}{l}\text { The quantitative randomized } \\
\text { study }\end{array}$ & $\begin{array}{c}151 \text { patients } \mathrm{FT}=76 \\
\text { non- } \mathrm{FT}=75\end{array}$ & $\begin{array}{l}\text { The nutrition - the fluid restriction and epidural analgesia in } \\
\text { FT are not connected to the clinically relevant haemodynamic } \\
\text { instability or renal dysfunction. }\end{array}$ & III \\
\hline
\end{tabular}

values of blood pressure. However, for the traditional access in the mentioned period it is nearly typical the aggressive fluid supply. The losses into the third space are just caused during the disorders of water balance and electrolytes. The aggressive fluid intake can also influence the cardiac functions - the congestion in small circulation, the swelling of lower limbs, the higher risk of pneumonia, the decreasing of tissue oxygenation, the swelling of intestinal wall leads to the gastrointestinal motility disorders. It threatens the risk of urinal retention as a result of the present exceeding water supply.

The fast track is based on the rational restriction of intravenous fluid intake, the infusion is ordained by a doctor. For most of the patients it is sufficient the fluid intake up to $2500 \mathrm{ml}$ per 24 hours, it depends on the range of operation intervention and the amount of blood loss during the performed operation [13,23]. The mentioned information is transmitted during the patient's transfer from the operating theatre, the physicians are actively warned of the possible abnormalities, the diuretics are applied in case of the cumulative balance.

\section{Nasogastric probe}

From the point of view of the traditional access the nasogastric probes are usual part of the certain operations, the probes are inserted in the long-term period and they are gradually removed according to the waste amount. If we speak about the early recovery of peroral intake so the nasogastric probes are just the one cause of delay of the early postoperative enteral alimentation and as for the planned operation intervention the mentioned probes should not be used at all. The insertion of the mentioned probes is associated with the higher risk of pneumonia, as well $[1,3,17,26]$.

In case of the fast track the usage of the nasogastric probes is sharply eliminated, the probes are inserted during the repeated vomiting and signs of the gastric overpressure. It is preferred the earlier and interrupted closing of the used probe (during the gastric residual volume making $<200 \mathrm{ml} / 6 \mathrm{hrs}$ ), for removing of the nasogastric probe it is tolerated $500 \mathrm{ml}$ of the residual volume $/ 24 \mathrm{hrs}$. And vice-versa after the vaster operation interventions the nasogastric probe is used for the application of enteral alimentation. The mentioned way of the used application of enteral alimentation can be used for the period of 6 weeks at the most. For the enteral alimentation lasting more than the mentioned 6 weeks they are used the nutritional stomia (the common insertion of nutritional jejunostomia during the performed operation intervention) which enable the patient's qualitative realimentation [27].

\section{Urinary catheters and drains}

The traditional access in the mentioned problems means the supposed benefit for all, i.e. for the patient, nurse, and physician. For example, when the catheterized patient has not the problems concerning retention, reaching the toilet and bed pollution. The patient's diuresis is exactly monitored. But generally, the all invasive accesses limit the patient's mobilization and they have the important psychological influence, the more hoses the more ill they feel and it is associated with the patient's unwillingness to participate in the rehabilitation procedures.

In the occupational conditions of the emergency care unit and in accordance with the ERAS concept we try for the early removing of the drain, probes and catheters which represent the infectious risk for the patient, including the movement limitation and psychological impact. It is recommended the early removing of used drains which have the minimum or no secretion at all during the last 24 hours $[3,28]$. If we put the question in spirit of the fast-track concept: "Does the patient still need the catheter?". We remove the urinary catheter in the 
1st - 3rd postoperative day in case it is not necessary to let it for the next exact monitoring of the patient's diuresis.

\section{Rehabilitation}

According to the traditional access the patients kept the strict calm in the bed during the operation day, the patients started to sit on the 1st postoperative day and only on the 2nd postoperative day they started to walk shortly and slowly and the most of day they spent in the beds.

The fast track in this case means sitting down of the patient already after 2 hours after the surgical intervention in the afternoon - in the evening we try the patient to stand near the bed and to walk around the bed. If the patient is able to perform the mentioned procedures, the walking length can be extended. On the first postoperative day we repeat the walking procedures with the nurse's assistance. The mentioned aimed effort means in its consequence the patients are already stand up on the day of performed operation and they are supported in walking in the department $[1,27]$.

The difficult rehabilitation occurs in the patients who do not want, they are not able, or they must not to stand up. We try to persuade them about the benefit of early mobilization through the suitable way. We attend to the sufficient analgesia, the non-steroid antiphlogistic and spasmolytic are preferred, it is recommended the decreased dose of the used opioid analgetics $[1,10,29]$.

The patients who are not able to stand up or they should not be stand up, it is performed the rehabilitation procedure within the patient's bed and it is provided the cooperation with the rehabilitation workers and the patient's family members are involved in the rehabilitation procedures, as well.

\section{ERAS protocol in the Czech Republic}

Only one survey focused on implementation of ERAS principles into practise in the Czech Republic has been published so far. Ryska, Šerclová and Antoš published the results of a national survey, which focused on compliance with modern perioperative care (ERAS) procedures at surgical workplaces in the Czech Republic. A questionnaire with 19 questions focused on the implementation of ERAS principles was sent to 148 surgical workplaces in the Czech Republic. 57 completed survey sheets from the total number of 148 sent questionnaires were returned to the sender's address (Table 2) [28].

GIT - Gastrointestinal tract; ERAS - Enhanced Recovery after Surgery Society; ESPEN - European Society for Parenteral and Enteral Nutrition; EBM - Evidence Based Medicine.

Limitation of the routine application of the nasogastric probe, application of epidural analgesia and parenteral preoperative nutritional support (if enteral not possible) reached the highest \% of use in practice.

\section{Discussion}

In the introduction it was already mentioned that introducing of the fast track in the perioperative care leads to the patient's recovery acceleration after the performed surgical intervention - decreasing of the perioperative stress [30,31], minimalizing of the postoperative complications [17], shortening of the hospitalization period $[18,19,26,31,32]$, the economic benefit $[6,20-22]$. However, they often struggle with the traditional concept, both in the medical staff and nurse staff, as well $[4,14,18,28,29]$.

The traditional concept of the patient's care in the perioperative period often looks in the individual stages as follows. In the preoperative period the patients undergo some additional or missing examinations during the hospitalization which could be performed, or which should be performed in the out-patient departments. The patients are exposed to the temporary fast in the hospital as a result of the mentioned performed examinations. The dogma concerning the prohibition of food and fluid intake from the midnight before the planned operations still persists in the most surgical workplaces $[3,28,33,34]$. It is still and routinely performed the mechanical pre-operation intestinal preparation $[1,28]$. The opiates are applied in the day of the planned operation, the patients are overloaded with the fluids, the patients can be overcooled during the surgical intervention, the drains and probes are inserted into the patient's bodies, the patient's mobilization usually continues in the day of performed operation [35,36]. The patients are banned from the intake per os in the postoperative period, the nasogastric probes, drains, central venous and urinary catheters are inserted into the patient's bodies for some days, the patient's nourishment is provided via the parenteral alimentation only. For an example, the certain fears predominate in the matter of vomiting, aspiration, and dehiscence of the intestinal anastomoses in the postoperative period during the early recovery of intake per os $[1,7]$.

The contemporary conception of the concept ERAS includes the innovations minimally in the twenty fields of the possible interventions - the patient's education, intestinal preparation, premedication, intake per os before the operation, anaesthesia, adequate volume therapy, incise, prevention of the postoperative hypothermia, analgesia, usage of the drains, nasogastric probes and catheters, prokinetics, postoperative intake per os, mobilization [1,34].

The patient's preparation, selection of premedication, type of anaesthetics, operation access and the most of the already mentioned interventions naturally depend on the physician's decision $[23,37]$.

It is elaborated the specific access as for the patients in the perioperative period, in the preoperative stage and operative and postoperative stage.

In the preoperative stage it is about the fields concerning the patient's education, limitation of intake per os in the operation day, preparation of the operation field [38-40]. During the operation stage it is important the selection of the suitable anaesthesia, keeping of normothermia during the surgical intervention, usage of the mini-invasive methods. The postoperative stage concerns of leaving of the drains, 
Table 2: Adherence to individual ERAS principles - summary of survey result.

\begin{tabular}{|c|c|c|c|c|}
\hline Question & Right answer & Guarantee of recommendations & EBM level & $\begin{array}{l}\text { Answer in accordance with the } \\
\text { recommendations }\end{array}$ \\
\hline Nutritional screening & Indicated in each patient before GIT surgery & ESPEN, ERAS & $\mathrm{Ilb}$ & $47 \%$ \\
\hline $\begin{array}{l}\text { Preoperative nutritional support in } \\
\text { patients indicated for GIT surgery }\end{array}$ & $\begin{array}{l}\text { It is performed at least } 2 \text { weeks before surgery in } \\
\text { patients at high risk of malnutrition }\end{array}$ & ESPEN & la & $37 \%$ \\
\hline $\begin{array}{l}\text { Method of administration of } \\
\text { preoperative nutritional support }\end{array}$ & Parenterally only if not enterally & ESPEN & $\mathrm{lb}$ & $67 \%$ \\
\hline Preoperative fasting & 6 hours solid food, 2 hours liquid & ERAS, ESPEN & la & $12 \%$ \\
\hline $\begin{array}{l}\text { Preoperative administration of a } \\
\text { carbohydrate drink }\end{array}$ & $\begin{array}{l}\text { The drink ( } 400 \mathrm{ml} \text { in total) should be given } \\
\text { routinely to each patient before the planned GIT } \\
\text { operation }\end{array}$ & ERAS & $\mathrm{Ilb}$ & $7 \%$ \\
\hline $\begin{array}{l}\text { Orthograde intestinal preparation } \\
\text { before GIT surgery }\end{array}$ & $\begin{array}{l}\text { It should not be used routinely (it is acceptable } \\
\text { before rectal surgery) }\end{array}$ & ERAS & la & $5 \%$ \\
\hline $\begin{array}{l}\text { Routine insertion of a nasogastric } \\
\text { tube }\end{array}$ & $\begin{array}{l}\text { The probe should not be routinely inserted. } \\
\text { Deployment is allowed for the duration of the } \\
\text { operation }\end{array}$ & ERAS & la & $59 \%$ \\
\hline $\begin{array}{l}\text { Routine insertion of a permanent } \\
\text { urinary catheter }\end{array}$ & $\begin{array}{c}\text { The catheter can be inserted for complicated } \\
\text { procedures in the small pelvis or operations lasting } \\
3 \text { hours or for postoperative retention }\end{array}$ & ERAS & $\mathrm{llb}$ & $36 \%$ \\
\hline $\begin{array}{l}\text { Routine insertion of the intra- } \\
\text { abdominal drain }\end{array}$ & $\begin{array}{l}\text { The intra-abdominal drain should not be } \\
\text { introduced routinely }\end{array}$ & ERAS & Ila & $9 \%$ \\
\hline $\begin{array}{l}\text { Postoperative restoration of oral } \\
\text { fluid intake }\end{array}$ & $\begin{array}{l}\text { The patient can receive fluids immediately after } \\
\text { the effects of anaesthesia have subsided }\end{array}$ & ERAS, ESPEN & $\mathrm{lb}$ & $2 \%$ \\
\hline $\begin{array}{l}\text { Postoperative restoration of oral } \\
\text { intake for solid food }\end{array}$ & $\begin{array}{l}\text { The patient can eat a mushy diet to taste on the } \\
\text { day of surgery }\end{array}$ & ERAS & $\mathrm{lb}$ & $2 \%$ \\
\hline $\begin{array}{l}\text { Indications for postoperative } \\
\text { nutritional support }\end{array}$ & $\begin{array}{l}\text { Indicated in patients with primary malnutrition or } \\
\text { suspected limited oral intake ( } 60 \%) \text { for } 10 \text { days }\end{array}$ & ERAS, ESPEN & $\mathrm{lb}$ & $42 \%$ \\
\hline $\begin{array}{l}\text { Initiation of enteral nutritional } \\
\text { support after surgery }\end{array}$ & $\begin{array}{l}\text { If indicated, nutrition should be started within } 24 \\
\text { hours of surgery }\end{array}$ & ESPEN, ERAS & $\mathrm{lb}$ & $35 \%$ \\
\hline Postoperative analgesia & $\begin{array}{c}\text { Continuous epidural analgesia with bolus } \\
\text { administration of a non-steroidal analgesic is } \\
\text { preferred }\end{array}$ & ERAS & la & $68 \%$ \\
\hline
\end{tabular}

nasogastric probes, early mobilization and peroral intake recovery.

Especially in the field of the patient's pre-operation preparation it came about the strong changes. In the many workplaces it is still common that the patient hungers for around 6-8 or more hours before the planned surgical intervention [28]. The new findings show that within the preoperative preparation the patients can take the clear and sweet liquids up to 2 hours before the surgical intervention naturally providing that the gastrointestinal passage in fully functional. It is supposed that during intake of $400 \mathrm{ml}$ of the such fluids the gastric volume will be evacuated within 90 minutes $[1,10,11]$. The patient's benefit is proved in the sense of the patient's sensation of thirst decreasing, sensation of mouth dryness, postoperative headache, mental stress and postoperative insulin resistance decreasing [9]. The physicians communicate the detailed information concerning the performed surgical intervention and postoperative course, they care of the non-aggressive fluid intake. The non-medical health staff is responsible for the correct preparation of the operation field (shaving via the electric shaver instead of the traditional shaving by means of a razor) and application of the prescribed premedication $[1,3]$. It also comes about the strong change as for the administration of premedication in the concept ERAS - it is often limited to the peroral administration of sedation in the evening before the planned operation only and with omission of the opiate and parasympatholytic drugs (Atropine).
The antibiotic prophylaxis is focused on the necessity of proper timing of the antibiotic application before the planned intervention, maximally $30 \mathrm{~min}$. before the introduction to anaesthesia (one of the possible ways is the antibiotic application only in the operating theatre in the introduction to anaesthesia). The selection of suitable antibiotics is performed according to the place and type of the surgical intervention and the bacterial risk level is taken into account, as well $[5,26]$.

During the operation stage it is placed emphasis on the selection of anaesthesia. The properly performed anaesthesia and analgesia decrease the stress neuro-endocrine respond of the organism to the surgical intervention [3,7,14]. Keeping of normothermia also contributes to decreasing of the perioperative blood loss and decreasing of the cardiac complications $[1,20,34]$. It is also placed emphasis on the selection of the suitable operation technique. It is preferred the usage of laparoscopic techniques and next minimally invasive accesses contributing to the patient's strong benefit when we minimalize the patient's operation trauma by means of the operation access reduction. Thanks to the minimum operation access and friendly operation techniques it comes about the lesser tissue traumatism along with the lower occurrence of possible complications, favourable postoperative course and shortening of the hospitalization period. In case of the choice of opened operation access there are preferred the transverse laparotomies prior to traditional longitudinal ones. In this way it comes about the reduction of postoperative pain [1-3], 
the occurrence of pulmonary complications and postoperative paralytic ileus $[9,14]$.

The postoperative stage is focused on the early removing of present drains, probes, and catheters. It is recommended the early mobilization of the patients participating in the intensive rehabilitation procedures. The recommended rest regimen in a bed leads to the loss of muscular tissue and weakness, the pulmonary function gradually deteriorates including the risk of phlebothrombosiss [9]. The early postoperative peroral intake or early enteral alimentation positively influences the postoperative glucose metabolism including the nitrogen substances and it also has the favourable effect on the peristaltic recovery, i.e. it is recommended chewing of the chewing gums [11].

The obstacles concerning the introduction of fast-track principles can be found in the insufficient number of the nursing staff (the staffing), they also lie in the material and device limitations (the lack of compensating aids for the rehabilitation procedures - the more available walkers). It results in unwillingness to introduce the new procedures "struggle" with the introduced traditions, the uncoordinated activity within the given hospital - it is missing the mutual and helpful cooperation of the professionals, in the insufficient teaching - the information transfer, experiences, the comparative trials, statistics - the traditional access vs. ERAS on the whole republic level.

Unfortunately, implementation in practise gets behind scientific reports almost decades.

\section{Conclusion}

It is proved the positive influence of the new way of perioperative care contained in the concept ERAS leading to the qualitative improvement of treatment and nursing process, the decreasing of postoperative complications, the shortening of hospitalization period, the decreasing of economical expenditures associated with the performed treatment and hospitalization of the surgical patients, the experiences and results can be the source of knowledge for the next surgical workplaces.

Despite of the unequivocal scientific proofs in the clinical practice concerning usefulness of the complex care the introduction of concept ERAS wrestles with the many problems in each workplace. It is especially evident in the items such as the early peroral intake, the early rehabilitation, the optimum analgesia, the early removing of the nasogastric probe, urinary catheter, and drains.

The introduction of the fast-track concept in postoperative care leads to the quicker patient's recovery after the surgical interventions including the shortening of hospitalization period. The successful basis of the mentioned method lies in the mutually connected procedures, the individually processed plan for each patient when the patient's base diagnoses and additional diseases must be taken into account.

The introduction of the mentioned concept in practice is to seek mainly due to the patient's benefit. The result is not only the less occurrence of postoperative complications, the shortening of hospitalization period but also the economic consequences resulting from the lower expenditures concerning the patient's treatment and nursing care.

Compared to the established ERAS protocol, the principles in the Czech Republic are applies less significantly and their adoption faces many problems in the workplaces. It is desirable for the concept ERAS to find the wider use in Czech health facilities.

\section{Author contributions}

JR, EM, IS: The concept and design, the data collection, the data analysis and interpretation, the draft of the handwriting processing, the critical final proof of the handwriting, the final refinishing of the handwriting.

\section{Acknowledgment}

Supported by a grant project of the Medical Faculty of the University of Ostrava in Ostrava with Reg. no.: SGS10 / LF / 2018.

\section{Conflict of interest statement}

All used bibliographic sources were properly quoted. The authors are not aware of the clash of interest in connection with the incurred article.

\section{References}

1. Satinský I, Schwarz P (2010) Koncept fast-track surgery a ošetřovatelský proces. In: Sborník př́spěvků V. slezské vědecké konference ošetřovatelstv s mezinárodní účastí. Opava: Slezská univerzita 241-243. Link: https://bit.ly/20896u9

2. Kehlet H, Wilmore DW (2008) Evidence-Based Surgical Care and the Evolution of fast-track Surgery. Ann Surg 248: 189-198. Link: https://bit.ly/38DqCjt

3. Šerclová Z (2009) Fast track ve střevní chirurgii, aktuální přehled. Rozhl chir 88: 527-535. Link: https://bit.ly/3faRJVb

4. Vlug MS, Bartels SA, Wind J, UbbinkDT, Hollmann MW, et al. (2012) Collaborative LAFA study group. Which fast-track elements predict early recovery after colon cancer surgery? Colorectal Dis 14: 1001-1008. Link: https://bit.ly/2BFbVjP

5. Varadhan KK, Lobo DN, Ljungqvist O (2010) Enhanced Recovery After Surgery: The Future of Improving Surgical Care. Crit Care Clin 26: 527-547. Link: https://bit.ly/3f9XIPz

6. Olsén MF, Wennberg E (2011) Fast-Track Concepts in Major Open Uppe Abdominal and Thoracoabdominal Surgery: A Review. World J Surg 35: 2586 2593. Link: https://bit.ly/3iAxbYq

7. Grigoras I (2007) Fast-track surgery - a new concept - the perioperative anesthetic management. J Chir 3: 184-195.

8. Gouvas N, Tan E, Windsor A, Xynos E, Tekkis PP (2009) Fast-track vs standard care in colorectal surgery: a metaanalysis update. Int $\mathrm{J}$ Colorectal Dis 24: 1119-1131. Link: https://bit.ly/3iOgd9|

9. Plodr M, Ferko A (2005) Fast track v chirurgii. Rozhl chir 84: 557-560.

10. Spelt L, Ansari D, Sturesson Ch, Tingstedt B, Andersson R (2011) Fast-track 
programmes for hepatopancreatic resections: where do we stand? HPB 13 833-838. Link: https://bit.ly/2ZPB8QA

11. Nygren J, Thacker J, Carli F, Fearon KC, Norderval S, et al. (2012) Enhanced Recovery After Surgery Society. Guidelines for perioperative care in elative rectal/pelvic surgery: Enhanced Recovery After Surgery (ERAS) Society recommendations. Clin Nutr 31: 801-816

12. Chen ZX, Liu AH, Cen $Y$ (2014) Fast-track program vs traditional care in surgery for gastric cancer. World J Gastroenterol 20: 578-583. Link: https://bit.ly/205azBl

13. Vymazal T (2014) Fast-track není jen fyziologická anestezie. Anest intenziv Med 25: 82-87.

14. Carli F, Phil M, Charlebois P, Baldini G, Cachero O, et al. (2009) An integrated multidisciplinary approach to implementation of a fast-track program for laparoscopic colorectal surgery. Can J Anaesth 56: 837-842. Link: https://bit.ly/3iHrKHd

15. Moher D, Liberati A, Tetzlaff J, Altman DG (2010) Preferred reporting items for systematic reviews and meta-analyses: The PRISMA statement. Int J Surg 8 : 336-341. Link: https://bit.ly/3fdKjRo

16. Guyatt GH, Haynes RB, Jaeschke RZ, Cook DJ, Green L, et al. (2000) Users Guides to the Medical Literature: XXV. Evidence-based medicine: principles for applying the Users' Guides to patient care. Evidence-Based Medicine Working Group. JAMA 284: 1290-1296. Link: https://bit.ly/2CcWdML

17. Šerclová Z, Dytrych P, Marvan J, Nová K, Hankeová Z, et al. (2009) Fast-track in open intestinal Surgery: Prospective randomized study. Clin Nutr 28: 618-624 Link: https://bit.ly/2CeaR6f

18. Wang Q, Suo J, Jiang J, Wang C, Zhao YQ, et al. (2011) Effectiveness of fasttrack rehabilitation vs conventional care in laparoscopic colorectal resection for elderly patients: a randomized trial. Colorectal Dis 14: 1009-1013. Link: https://bit.ly/3e99F1n

19. Lemanu DP, Singh PP, Berridge K, Burr M, Birch C, et al. (2013) Randomized clinical trial of enhanced recovery versus standard care after laparoscopic sleeve gastrectomy. Br J Surg 100: 482-489. Link: https://bit.ly/2DmsxgE

20. Varadhan KK, Neal KR, Dejong CH, Fearon KC, Ljungqvist O, et al. (2010) The enhanced recovery after surgery (ERAS) pathway for patients undergoing major elective open colorectal surgery: A meta-analysis of randomized controlled trials. Clin Nutr 29: 434-440. Link: https://bit.ly/3fb0FKs

21. Ren L, Zhu D, Wei Y, Pan X, Liang L, et al. (2012) Enhanced Recovery After Surgery (ERAS) Program Attenuates Stress and Accelerates Recovery in Patients After Radical Resection for Colorectal Cancer: A Prospective Randomized Controlled Trial. World J Surg 36: 407-414. Link: https://bit.ly/3iRmAZs

22. Hübner M, Schäfer M, Demartines N, Müller S, Maurer K, et al. (2012) Impact of Restrictive Intravenous Fluid Replacement and Combined Epidural Analgesia on Perioperative Volume Balance and Renal Function Within a Fast Track Program. J Surg Res 173: 68-74. Link: https://bit.ly/3eemSWt

23. Zeman M, Krška Z (2011) Chirurgická propedeutika. Praha: Grada. Link: https://bit.ly/38GqyPY

24. Barlow R, Price P, Reid TD, Hunt S, Clark GW, et al. (2011) Prospective multicentre randomised controlled trial of early enteral nutrition for patients undergoing major upper gastrointestinal surgical resectionq. Clin Nutr 30 : 560-566. Link: https://bit.ly/2BOV26b
25. Krška Z (2011) Techniky a technologie chirurgických oborech. Praha: Grada Link: https://bit.ly/20277aC

26. Vlug MS, Wind J, van der Zaag E, Ubbink DT, Cense HA, et al. (2009) Systematic review of laparoscopic vs open colonic surgery within an enhanced recovery programme. Colorectal Dis 11: 335-343. Link: https://bit.ly/3gvu5Dk

27. Lemanu DP, Singh PP, MacCormick AD, Arroll B, Hill AG (2013) Effect of Preoperative Exercise on Cardiorespiratory Function and Recovery After Surgery: a Systematic Review. World J Surg 37: 711-720. Link: https://bit.ly/3gHzfvR

28. Ryska O, Šerclová Z, Antoš F (2013) Jak jsou dodržovány postupy modern perioperační péče (Enhanced Recovery After Surgery) na chirurgických pracovištích v ČR - výsledky národní ankety. Rozhl chirurgii 92: 435-442.

29. Bláha J, Klozová R, Nosková P, Seidlová D, Štourač $P$, et al. (2015) Současné postupy $\mathrm{v}$ porodnické anestezii $\mathrm{V}$. - pooperační péče po císařském řezu. Anest intenziv Med 26: 87-98.

30. Kuthan D, Ludvík $P$, Poděbradský J, Kořínek $P$ (2008) Naše první zkušenost s metodou fast track v léčbě kolorektálního karcinomu. Rozhl chir 87: 125-127.

31. Keane C, Savage S, McFarlane K, Seigne R, Robertson G, et al. (2012) Enhanced recovery after surgery versus conventional care in colonic and rectal surgery. ANZ J Surg 82: 697-703. Link: https://bit.ly/3iDHmLU

32. Wind J, Hofland J, Preckel B, Hollmann MW, Bossuyt PM, et al. (2006) Perioperative strategy in colonic surgery, Laparoscopy and/or Fast track multimodal management versus standard care (LAFA trial). BMC Surg 29: 16 Link: https://bit.ly/2BF8E41

33. Ljungqvist O (2011) ERAS - Enhanced recovery after surgery. J Visc Surg 148: 157-159. Link: https://bit.ly/2VVmypi

34. Ionescu D, lancu C, Ion D, Al-Hajjar N, Margarit S, et al. (2009) Implementing Fast-Track Protocol for Colorectal Surgery: A Prospective Randomized Clinical Trial. World J Surg 33: 2433-2438. Link: https://bit.ly/207VzTs

35. White PF, Kehlet H, Neal JM, Schricker T, Carr DB, et al. (2007) Fast-Track Surgery Study Group. The Role of the Anaesthesiologist in Fast-Track Surgery: From Multimodal Analgesia to Perioperative Medical Care. Anesth. Analg 104 1380-1396. Link: https://bit.ly/2ChYTsc

36. Li C, Carli F, Lee L, Charlebois P, Stein B, et al. (2013) Impact of a trimodal prehabilitation program on functional recovery after colorectal cancer surgery: a pilot study. Surg Endosc 27: 1072-1082. Link: https://bit.ly/2VVmeXC

37. van Bree SH, Vlug MS, Bemelman WA, Hollmann MW, Ubbink DT, et al. (2011) Faster Recovery of Gastrointestinal Transit After Laparoscopy and Fast-Track Care in Patients Undergoing Colonic Surgery. Gastroenterology 141: 872-880. Link: https://bit.ly/2ZSyoSk

38. Schumpelick V (2013) Chirurgie - stručný atlas operací a výkonů. Praha: Grada. Link: https://bit.ly/3edqat8

39. Gustafsson UO, Scott MJ, Schwenk W, Demartines N, Roulin D, et al. (2013) Guidelines for Perioperative Care in Elective Colonic Surgery: Enhanced Recovery After Surgery (ERAS) - Society Recommendations. World J Surg 37 259-284. Link: https://bit.ly/2VXIEYC

40. Fineout-Overholt E, Johnston L (2005) Teaching EBP: A challenge for educators in the $21^{\text {st }}$ Century. Worldviews Evid Based Nurs 2: 37-39. Link: https://bit.ly/3fnjavr

Copyright: (c) 2020 Richtarova J, et al. This is an open-access article distributed under the terms of the Creative Commons Attribution License, which permits unrestricted use, distribution, and reproduction in any medium, provided the original author and source are credited.

Citation: Richtarova J, Mrazkova E, Satinsky I (2020) The effectiveness of the concept ERAS (Enhanced Recovery After Surgery) in patients of surgical intensive care unit. Glob J Perioperative Med 4(1): 001-008. DOI: https://dx.doi.org/10.17352/gjpm.000007 